\title{
The Use of the Balanced Scorecard in Small Companies
}

\author{
George Giannopoulos ${ }^{1}$, Andrew Holt ${ }^{2}$, Ehsan $\operatorname{Khansalar}^{1} \&$ Stephanie Cleanthous ${ }^{1}$ \\ ${ }^{1}$ Kingston Business School, Kingston University, London, UK \\ ${ }^{2}$ Department of Accounting, Metropolitan State University of Denver, Denver, USA \\ Correspondence: Andrew Holt, Department of Accounting, Metropolitan State University of Denver, Campus \\ Box 80, P.O. Box 173362, Denver, Colorado, 80217-3362, USA. E-mail: aholt7@msudenver.edu
}

Received: April 9, 2013 Accepted: May 20, 2013 Online Published: June 18, 2013

doi:10.5539/ijbm.v8n14p1 URL: http://dx.doi.org/10.5539/ijbm.v8n14p1

\begin{abstract}
The Balanced Scorecard (BSC) is a performance measurement and strategic management system which appears suitable for use by all types and sizes of business. The BSC's greatest strength for most businesses comes from its innate ability to integrate financial and non-financial measures together by measuring both strategic and business performance across four interrelated perspectives. Many studies have shown that the BSC can be successfully implemented within large-scale companies and organizations. However, there is limited empirical evidence regarding the use of the BSC within small companies. This study adds to the existing literature by reporting the results of a comparative investigation of BSC awareness and use within small companies located in the UK and Cyprus. In addition, the study examines the reasons for non-adoption by small companies and whether these companies use performances measures that are similar to those typically contained within the BSC model. The research data was collected from self-completed questionnaires that were distributed to 500 companies in the UK and Cyprus. The findings of the survey suggest that the majority of small companies, especially in the UK, are unaware of the BSC, and consequently levels of BSC usage are extremely low. Certain respondents believed that BSC is an unsuitable tool for small companies and that its implementation is beyond the resources available to such entities. However, the findings also suggest that even though very few small companies actually use the BSC, many such companies appear to use performances measures and indicators similar to those typically included within a BSC model.
\end{abstract}

Keywords: Balance Scorecard, BSC, small companies, strategic performance management system, financial measures, non-financial measures

\section{Introduction}

The Balanced Scorecard (BSC) is a strategic performance management system used by many companies in the international business environment. According to Kaplan and Norton $(1992 ; 1996 \mathrm{a})$, the creators of BSC, this tool can balance both the financial and non-financial measures that a company uses. It is separated into four perspectives - customer perspective, internal business perspective, innovation and learning perspective and financial perspective. According to Gumbus and Lussier (2006), the BSC can be used in both large and small businesses if employees are working towards achieving the same targets and strategic goals.

Numerous surveys have provided evidence as to the BSC's popularity and widespread implementation by different types of organization (Rigby and Bilodeau, 2011). One such survey was undertaken for The Chartered Institute of Management Accounting (CIMA) by the International Institute of Banking and Finance Services in 2009 (IIBS) (CIMA, 2009). According to this survey, the BSC continues to be one of the most popular management tools and the most likely to be adopted by companies (CIMA, 2009). More recently, a 2011 survey of management tools and techniques conducted by Bain \& Company found that the BSC was one of the 25 most popular tools and its use was projected to keep increasing (Rigby and Bilodeau, 2011).

Although the BSC has been successfully adopted by many large corporate businesses and non-profit organizations, it has been subject to criticism from both theorists and practitioners (Kaplan and Norton, 2001; Norreklit 2000). Despite its critics, the BSC has produced tangible benefits for many of the large organizations who have chosen to implement it. Theorists predict similar benefits for smaller companies and entities who decide to adopt and implement the BSC (Bergen and Benco, 2004). Despite this, there is little empirical evidence about the levels of BSC implementation by small companies. 
For the purposes of this present study, suitable definitions for a 'small company' must be devised for use in both the UK and Cyprus. In the UK, according to section 382 of the Company Act 2006, a company is considered as a small company if it meets two or more of the following requirements:

- A turnover no more than $£ 6.5$ million.

- A balance sheet total of assets no more than $£ 3.26$ million.

- No more than 50 employees.

In Cyprus, the Ministry of Commerce Industry and Tourism in Cyprus defines a small company as one which has no more than 10 employees (Ministry of Commerce Industry and Tourism in Cyprus, 2012).

Small companies usually have a simple organizational structure and their management system is controlled by their leader - which usually is the owner - with the help of few managers (Anderson, Cobbold and Lawrie, 2001). However, it is important that small companies still have a clearly defined strategy and should be able to measure their performance in order to survive in the competitive business environment.

Existing literature regarding the application of the BSC in small companies is extremely limited (Anderson, Cobbold and Lawrie, 2001). This study aims to provide new empirical insights into the use of the BSC by small companies by conducting a comparative survey of small companies located in the UK and Cyprus.

\subsection{Aims and Objectives of the Study}

\subsubsection{Aims}

This study explores whether the BSC is known and used by small companies. In addition, it provides information about possible reasons that BSC might not be used by this size of companies. This information is provided after a survey has been launched in a sample of UK and Cypriot small companies. Moreover, this study focuses its investigation on BSC as a strategic performance management system, created by Kaplan and Norton (1992; 1996a, 1996b, 1996c) and divided into four perspectives which are the customer perspective, internal business perspective, innovation and learning perspective and financial perspective. The findings and results from this research provide much needed information about the use of the BSC by small companies.

\subsubsection{Objectives}

This study has four main objectives, which are:

- To investigate whether management in small companies are aware of the BSC model.

- To identify the levels of BSC implementation within small companies.

- To explore the reasons of non-adoption of BSC by small companies.

- To examine whether small companies use performance measures similar to those used within the BSC

\subsection{Structure}

The rest of this study is divided into four sections:

- Section 2 explains the concept of BSC and its use as a measurement and strategic management system within small entities. There is a basic critique of the BSC.

- Section 3 provides information about the selected research paradigm and the methods of data collection and analysis used. Moreover, there is a discussion regarding the limitations of the selected methods and an analysis of the terms of generalisability, reliability and validity of the data collection.

- Section 4 discusses the findings of the survey from each country and provides a comparative analysis of the results. In addition, there is a discussion about limitations of this research and suggestions for further research regarding BSC.

- Section 5 provides a conclusion and concluding comments about the significance of the study.

\section{Literature Review}

\subsection{Objectives}

The main objective of this section is to critically evaluate the BSC literature.

\subsection{Introduction}

This section is divided into four subsections. The first subsection discusses the concept of BSC as a measurement and as a strategic management system. The second subsection analyses the four perspectives of the 
BSC, while the third subsection discusses the use of BSC in small entities. Finally, there is a subsection presenting a critique on BSC and a subsection which concludes this section.

\subsection{The Balanced Scorecard}

The Balanced Scorecard (BSC) is a performance measurement system which was developed by Kaplan and Norton in 1992 in order to address the limitations of the use of the traditional financial performance measurement systems (Kaplan and Norton, 1992). The financial accounting measures that are generally used by companies include the return on investment (ROI) and the earnings per share (EPS). As Kaplan and Norton stated (1992), these measures produce results by relying on past performances. In the competitive environment of nowadays this kind of information may be misleading/insufficient especially in areas relating to the development and the innovation of the company.

Main characteristic of BSC is that it uses both financial and non-financial measures in order to establish a complete view regarding the company's performance (Kaplan and Norton, 1992; 1996a). Over the years, the BSC has been improved and advanced into a measurement system but more importantly into a strategic management system. Both of these aspects are elaborated and discussed below.

\subsubsection{The BSC as a Performance Measurement System}

The BSC is a dynamic tool that can be used to implement a company's strategy from theory into practice. According to Kaplan and Norton (1992), the BSC includes a number of measures that allow the managers to have a quick but complete view of the company. Specifically it is stated that 'the Balanced Scorecard translates an organization's mission and strategy into a comprehensive set of performance measures that provides the framework for a strategic measurement and management system' (Kaplan and Norton, 1996a, p.2). Additionally, the BSC has the ability to align the management processes of a business and gives emphasis to the implementation of long-term strategy (Kaplan and Norton, 1992; 1996b).

\section{Translating Vision and Strategy: Four Perspectives}

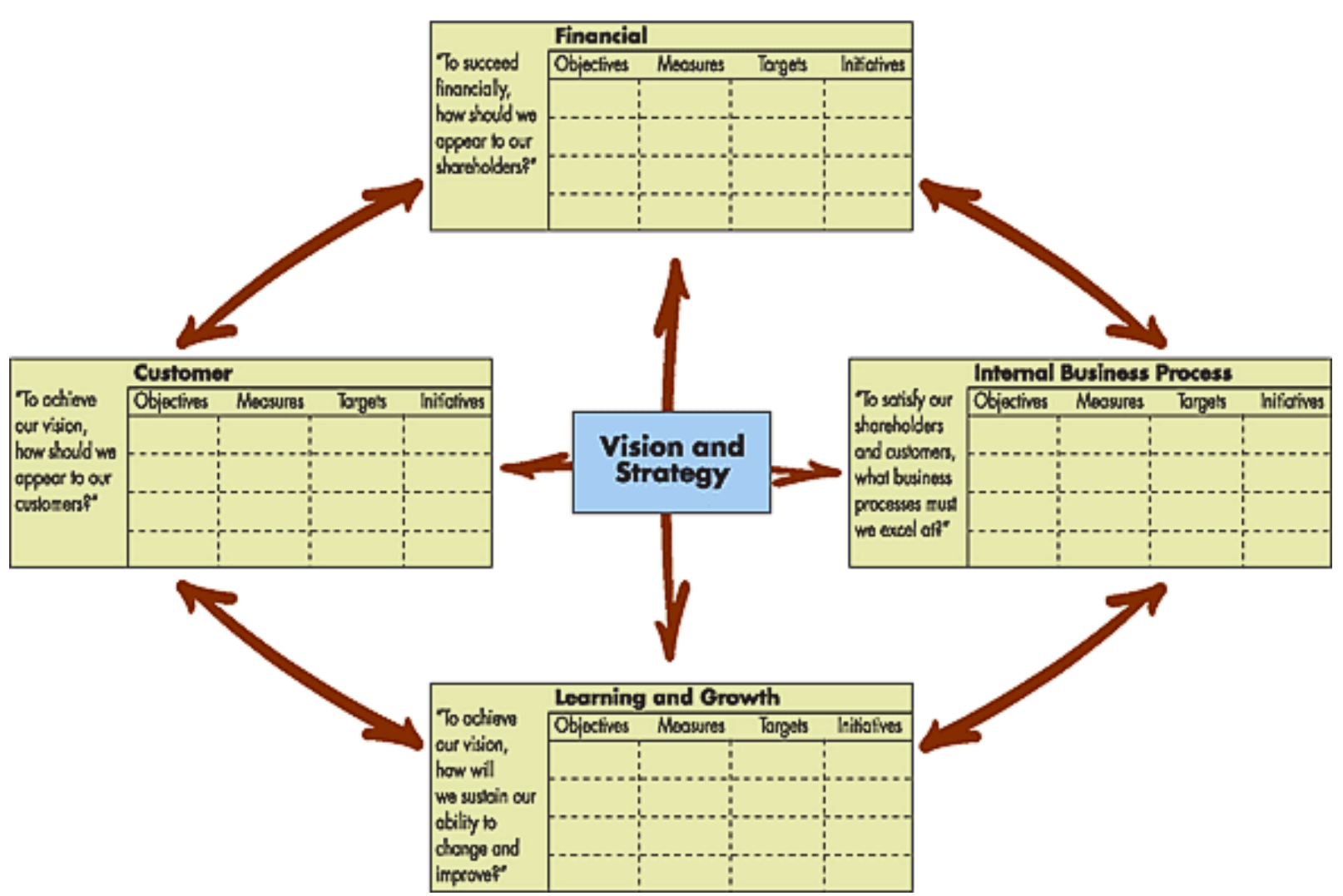

Figure 1. The four perspectives of the balanced scorecard

Source: Kaplan \& Norton, 1996b, p.76. 
The BSC model shown in Figure 1 utilises an appropriate combination of leading and lagging performance indicators to measure performance across four interrelated perspectives. Selection of these performance measures is determined by answering the following fundamental questions about each of the four perspectives within the model (Kaplan and Norton, 1992; Collis, Holt and Hussey, 2012):

- Customer perspective - How do customers see us?

- Internal business perspective - What must we excel at?

- Innovation and learning perspective - Can we continue to improve and create value?

- Financial perspective - How do we look to shareholders? (Kaplan and Norton, 1992)

In addition, a critical assumption of the BSC is that a cause-and-effect relationship exists among the financial and non financial measures, which involves a connection from the formulation of the strategy to financial outcomes (Kaplan and Norton, 1992; Collis, Holt and Hussey, 2012; Sinha, 2006). In order to have an improvement in the internal business processes then an improved learning and growth performance is essential, and consequently the customer perspective will be improved as well. As a result, the improved results of the customer satisfaction will significantly improve and increase the financial returns (Collis, Holt and Hussey, 2012; Sinha, 2006).

\subsubsection{The BSC as a Strategic Management System}

Some businesses moved beyond using the BSC as a performance measurement system and identified its value as a strategic management system (Anthony and Govindarajan, 1998; Bose and Thomas, 2007). Consequently, the concept of the BSC was enhanced in order to be also used as a strategic management system (Kaplan and Norton, 1996b; Cobbold and Lawrie, 2002; Sinha, 2006). Kaplan and Norton (1996b), stated that the BSC has the ability to allow managers to create and introduce four new management processes which can be used individually or in combination, in order to relate the long-term strategic objectives with short-term actions (Kaplan and Norton, 1996b). As shown in Figure 2, the four management processes are identified as:
a) translating the vision/strategy of the business
b) communicating and linking the vision/strategy of the business with its employees
c) business planning to achieve vision/strategy, and
d) feedback and learning to evaluate and adjust the existing strategy.

\section{Managing Strategy: Four Processes}

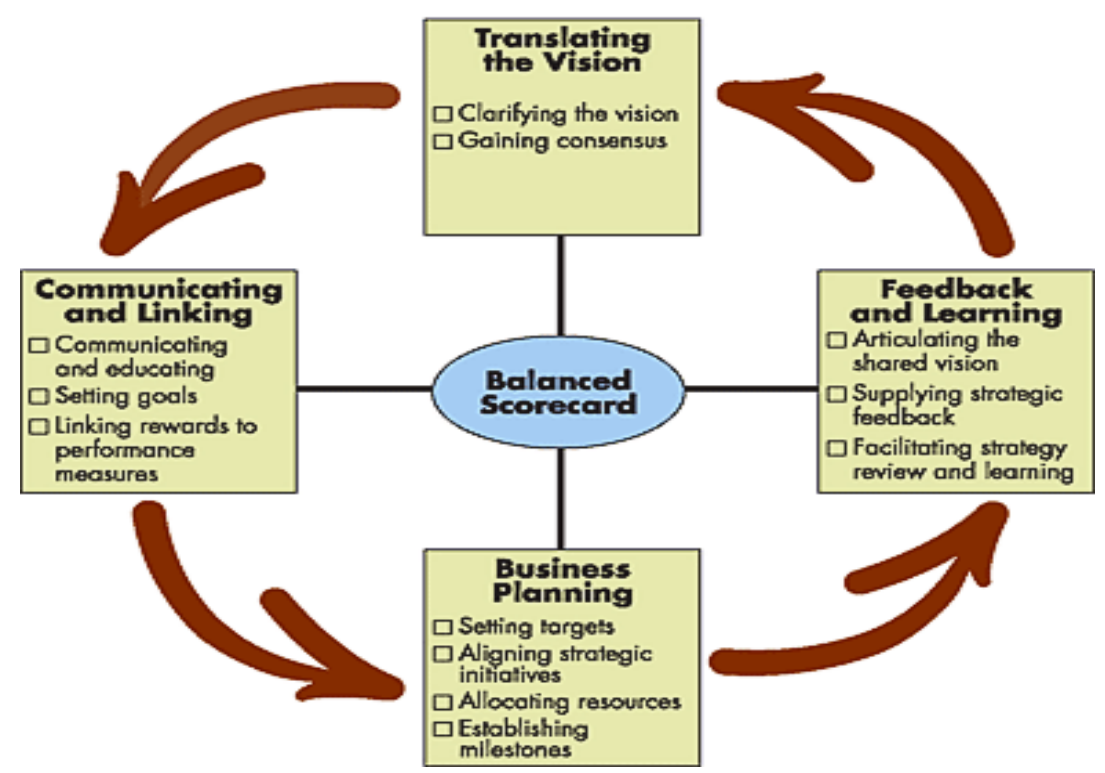

Figure 2. The four processes of the BSC

Source: Kaplan \& Norton, 1996b, p.77. 


\section{Communicating and linking process}

The second process of the BSC enables managers to ensure that the strategy of the business has been understood from all the levels of the business. Specifically this process offers an efficient structure by which managers can disseminate the long-term vision and strategy of the business to all employees by communicating the strategy and allowing it to be aligned with personal goals (Kaplan and Norton, 1996b). Moreover the long-term strategic goals have to be aligned not only with the departmental goals but also with the individual goals, which subsequently should be aligned to each other for realizing the long-term goals (Sinha, 2006). In order to link the strategy of the business with the individual performances of the employees, this process offers three activities: communicating and educating, setting goals and linking rewards to performance measures (Kaplan and Norton, 1996b).

\section{Business planning process}

This process allows the businesses to combine their financial and business plans (Kaplan and Norton, 1996b). Managers within the majority of businesses have to cope with the complexity of incorporating various initiatives in order to reach its strategic goals. Moreover, failure to achieve strategic goals could lead to frequent disappointments within the business and specifically among its employees and managers. The proposed business planning process has the ability to authorize managers to allocate the resources and set priorities in order to undertake and manage only the initiatives that are essential for the long-term goals (Kaplan and Norton, 1996b; Sinha, 2006).

\section{Feedback and learning process}

The first three processes help the business with their strategic implementation process. However, in order to establish whether the business is able to achieve its strategic goals, the feedback and learning process is vital (Sinha, 2006). This process provides feedback on whether the business has achieved its budgeted financial goals, evaluates and reviews the existing strategy enabling adjustments wherever is needed (Kaplan and Norton, 1996b; Sinha, 2006).

Furthermore, with the feedback and learning process the company is able to identify if the cause-and-effect relationships between the four different perspectives exist, how strong are these relationships and finally if the results that are gained are positive or negative. If a gap in the cause-and-effect relationships is identified then the business should perform immediate corrections in order to establish a positive relationship between the diverse factors. Finally, the feedback and learning process might force/lead a business to make changes in the set of measures of each perspective and implement those which will guarantee successful corporate and business strategies (Sinha, 2006).

\subsection{The Four Perspectives of the BSC}

As mentioned before, the BSC is divided into four perspectives; customer perspective, internal business perspective, innovation and learning perspective and financial perspective. In order to give the full meaning of the BSC as a measurement system the four perspectives are analyzed and discussed below.

\subsubsection{Internal Business Perspective}

The internal business perspective focuses on the activities an organisation undertakes to satisfy its customers. For example, in a manufacturing organisation, assembly of a product is an internal business process.

\subsubsection{Innovation and Learning}

The innovation and learning perspective focuses on the capabilities and skills that the company must excel at to achieve superior internal business processes that create value for customers and shareholders. Some of the performance measures that might be used to measure innovation and learning include employee education and skill level, employee satisfaction and retention rates.

\subsubsection{Customer Perspective}

The customer perspective focuses on the customers' opinion for the company, and how the company wants to be viewed by its customers (Norreklit, 2000). The satisfaction of the customers is a priority to many businesses, especially nowadays where the business environment is even more competitive (Kaplan and Norton, 1992), and can also act as a very important key performance indicator on the efforts of the business to be successful (Anderson and Sullivan, 1994). The customers usually have four main concerns regarding the product or service that is offered by a business: time, quality, performance \& service and cost. Therefore, the company has to align its targets according to these four elements, and subsequently transform these targets into specific measures (Kaplan and Norton, 1992). 


\subsubsection{Financial Perspective}

The financial perspective is the last perspective of the model of BSC. This perspective refers to the financial view of a company as presented to its shareholders and whether the strategy, implementation and execution of the company are contributing to bottom-line improvement (Kaplan and Norton, 1992). The financial performance measures provide information based on company results of past events. The measures as well as the objectives of the other three perspectives of the BSC focus on the financial targets and objectives, which generally have to do with growth, profitability and shareholder value (Kaplan and Norton, 1996a). However Kaplan and Norton (1992) state that because the financial indicators do not influence customer's and employee's satisfaction the businesses should not use them as metrics to direct them to their strategic vision. As a result, the businesses should not use only financial data but also strategy models and measurements that emphasize to the total of the business's strategy.

Indicatively some of the financial measures that can be used are: gross margin percentage, cost reductions in key areas, return on investment and return on capital employed (Collis, Holt and Hussey, 2012; Kaplan and Norton, 1996a).

\subsection{The Use of the Balanced Scorecard in Small Entities}

Since its initial development in 1992, the BSC has been subject to many empirical studies about its adoption and use within larger entities. In contrast, limited empirical evidence is available about its application and use within small entities (Russo, 2005; McAdam, 2000; Zinger, 2002).

Bain \& Company produce an annual survey of 'Management tools and techniques' that includes data about the popularity and use of the BSC in both large-scale and small-scale entities. The last survey was conducted in 2011 and included data from 1,230 management executives at a range of industries from various countries. The latest survey highlights that larger businesses uses on average 30\% more management tools than smaller businesses, with smaller businesses using an average of nine management tools during 2008 and eight in 2010 (Rigby and Bilodeau, 2011). The results also reveal that the BSC was one of the 25 most popular management tools during 2011 and its level of usage increased from $47 \%$ to $63 \%$ between the years 2010 to 2011 . Further longitudinal analysis reveals that the BSC has risen from $13^{\text {th }}$ more popular management tool to $6^{\text {th }}$ most popular during the period 2004-10 (Rigby and Bilodeau, 2011). Moreover, according to the same survey in 2010 the BSC had total usage of $48 \%$ (approximately) of the participant corporations and overall satisfaction almost 4 out of 5 which was the highest satisfaction level (Bain \& Company guide, 2010).

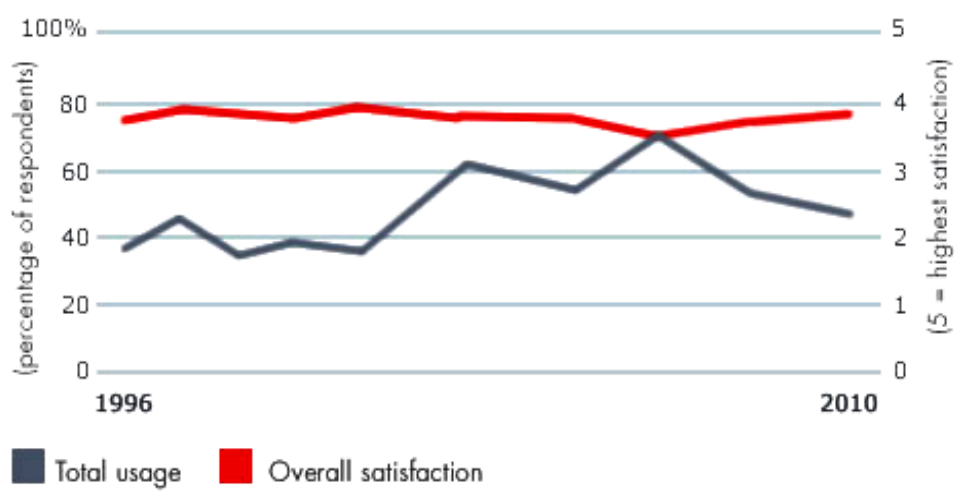

Figure 3. Total usage and overall satisfaction with the BSC 1996-2010

Source: Bain \& Company, 2010.

In 2009, a survey was conducted for the Chartered Institute of Management Accounting (CIMA) by the International Institute of Banking and Finance Services (IIBS) regarding current and intended usage of more than 100 management accounting and related tools (CIMA, 2009). The survey was completed by 439 respondents, from different sectors, regions and organization sizes in July 2009. According to CIMA's survey, the BSC is the most popular tool and considered as the one most likely to be adopted soon. Additionally the survey showed that the BSC is generally used by large companies rather than small. To be more specific, from the companies that were surveyed almost $60 \%$ of the very large companies and $40 \%$ of the large companies use BSC as a 
performance management tool. In addition, only $25 \%$ of the small companies use the model of BSC as a performance management tool. However, as we can see from the graph provided in the survey regarding the interest in performance management tools by size of organization, the BSC is the most popular performance management measure among the others and the most widely used (CIMA, 2009). It should be noted here that the BSC was initially designed in order to be used by medium and large companies. This was due to the fact that small companies have different characteristics that distinguish them from the majority of the large companies (Hudson, Smart and Bourne, 2001).

Moreover, there is a possibility that some of the small companies that argue that they do not use the BSC might actually use it without realizing it. The managers of these small companies might produce performance management systems that are similar to the BSC. Therefore, they might use the same structure or some of its perspectives as a performance measure without being aware of it.

\subsection{Critique of Balanced Scorecard}

Although there are many advocates and proponents of the BSC, the model and its approach are not free from criticism. Norreklit (2000) argues that the cause-and-effect relationship between measures from the four perspectives of BSC which Kaplan and Norton explained (1996a; 1996c), is problematic. The cause and effect that exist between the four perspectives is measured at the same time and any time lag that might exist is ignored. The fact that time dimension is not part of the BSC makes the tool problematic. However, the consequences of the measures will arise at different times, and this is because the consequences of each different area have different time scales. The BSC should help the businesses to develop and improve the four perspectives at the same time but the effects will appear at different points of time. For example, when new, more efficient processes are introduced in the business, they may improve the customer satisfaction within a two months period but on the other hand financial results may not be affected until few years have passed. Some processes may show their effects almost immediately whereas others will take much longer to do so. Due to the fact that BSC does not include the time dimension, it may be problematic and impractical to measure the effect of a new and complex action. Additionally it is considered to be hard or even not possible for a company to find performance measures for actions that are new and in effect inexperienced (Norreklit, 2000). Additionally it is argued that, it is hard to measure the effects in businesses, where innovation is very crucial and significant to their competitiveness and they regularly have to settle in to new situations (Norreklit, 2000; Schoenfeld, 1991).

Furthermore, the BSC ignores the competition and technological developments which are very important factors for companies nowadays. Specifically the fact that the BSC does not take into account continuous examination of the actions of the competitors and of the technological developments, makes the tool to be static instead of dynamic. Moreover, the BSC has risks which are too rigid because although it measures what the strategy requires to be set, it does not ask about what may block or cause problems to the strategy. As a result the failure to identify problems to the strategy will create a gap among the strategic plan and the actual strategy that is adopted (Norreklit, 2000).

\subsection{Conclusion}

This section critically evaluates the BSC literature. In particular this section discusses the use of BSC as a measurement and strategic management system and analyses its four perspectives. Moreover, there is a discussion about the use of BSC in small companies and a criticism about its efficiency.

\section{Methodology and Data}

\subsection{Objectives}

The first objective of this section is to explain the methodology chosen to investigate the objectives of this study. The second objective is to display the data selection process.

\subsection{Introduction}

This section is divided into four subsections and discusses a number of different ways to conduct research. The first subsection analyses and explains the selected research paradigm while the second subsection discuses the terms of generalisability, reliability and validity. In the third subsection there is a discussion about the methods with which the selected data is collected and analysed. The fourth subsection provides an analysis over the scope of this survey. Moreover, there is a discussion about the limitations of the selected methods at the end of this section. A final subsection concludes this section.

\subsection{Research Paradigm}

One of the most important factors that you have to identify and define when selecting a research methodology is 
the research paradigm. For a researcher, it is crucial to identify and understand his personal paradigm as this will decide the whole course of the research assignment. According to Collis and Hussey (2003, p.46), 'the term paradigm refers to the progress of scientific practice based on people's philosophies and assumptions about the world and the nature of knowledge'. The paradigm offers a framework that includes a set of acceptable theories, methods and ways of data analysis. However, the term 'paradigm' in the academic research has been used relatively freely with different meanings to different people (Collis and Hussey, 2003). In order to elucidate any doubts, Morgan (1979) recommends that the term 'paradigm' may be divided into three levels; firstly the philosophical level, where the term is used to reflect fundamental ideas about the world; secondly, the social level, where the term is used to offer guidance about how the person who carries out the research should conduct his attempt; thirdly, the technological level, where the term is used to define the techniques and methods that have to be used when carrying out a research.

There are two types of data that can be collected for a research; the quantitative and the qualitative. According to Collis and Hussey $(2009$, p. 63) quantitative data is defined as the 'data in a numerical form' and the qualitative data as the 'data in a nominal form such as words, images and so on'. In general, positivist studies include quantitative data while interpretivist studies include qualitative data (Collis and Hussey, 2009). This research uses both quantitative and qualitative data in order to fully meet its objectives. Additionally, the paradigm used is neither positivist nor interpretive, but it lies between these two paradigms.

\subsection{Generalisability, Reliability and Validity}

According to Brennan $(2010$, p.2) 'generalisability theory offers an extensive conceptual framework and a powerful set of statistical procedures for addressing numerous measurement issues'. Moreover, generalization is concerned with the use of results from a research of other cases with other conditions different from those examined in the research (Collis and Hussey, 2009). In this research project the concept of generalisability is included. This is because the results and observations of this project provide useful information that will be available for further research into topics which are related to BSC and its use within small companies.

The concept of reliability 'refers to the extent to which your data collection techniques or analysis procedures yield consistent findings' (Saunders, Lewis and Thornhill, 2009 p.156). When the results of a research are considered to be reliable, it means that if the research is repeated it will produce the same results (Collis and Hussey, 2009).

Collis and Hussey (2009, p.64), stated that validity is 'the extent to which the research findings accurately reflect the phenomena under the study'. In other words validity is concerned with whether the results of the research are 'really about what they appear to be about' (Saunders, Lewis and Thornhill, 2009, p.157).

Both reliability and validity are very significant and crucial for this research project. This is because one of the objectives of this research is for its results to provide important and useful information for the owners of small companies. Moreover, by achieving all of the objectives of this research and accurately answering the research questions, this will result to a better understanding of the concept of the BSC and the reasons whether or not it is suitable for use within small companies.

\subsection{Methods of Data Collection and Analysis}

There are a number of different methodologies and methods that a researcher can use in order to collect as well as to analyse data. Each method and methodology is depended on the conditions and purposes of the research, and also on the information that is available. The collection of the research data has been categorized into primary and secondary data. The primary data is the one that it is collected from an original source and the secondary data is the one that is collected from sources that already exist (Collis and Hussey, 2003). Both primary and secondary data is used for the purposes of this research.

\subsubsection{Secondary Data}

The first step of a research project is the collection of secondary data, since important and helpful information can be provided through out that can be used for the literature review. For this study it is essential to gather information from appropriate books, journals and online academic databases in order to understand the concept of BSC and consequently identify all the relevant knowledge and theories which are related with this topic.

However, there is a possibility that the secondary data may not be suitable or may not be adequate for the topic which the researcher wants to study (Kothari, 2004). In addition, sometimes the information included in personal reports may not be objective and precise, since the writers of such reports many times express their own thoughts and views (Kumar, 2005). Therefore, it is very important that before using the secondary data the researcher examines the reliability, the suitability as well as the adequacy of the data (Kothari, 2004). As a result, the 
secondary data that is used in this research project are selected from relevant books and journals as well as online academic databases such as Science Direct and SSRN.

\subsubsection{Primary Data}

This research required not only secondary data but also primary data. The primary data was collected by questionnaires that were sent to respondents in small companies in the UK and Cyprus.

When the self-completed questionnaire method is applied for a survey there are different distribution methods, including via telephone, post, online and face-to-face as well as individual distribution and group distribution. Usually, the most common factors that affect the choice of the distribution method are cost, the size of the sample and also the location of the sample (Collis and Hussey, 2009). For this research project the method selected for distribution of the self-completion questionnaires was the online survey, as it was relatively inexpensive and less time consuming to administer than the alternatives. Moreover, by using this method it was easier to manage a large sample.

\subsubsection{Design of the Questionnaire}

The questionnaire was designed and administered using the Qualtrics software package. The questionnaire included relevant questions for examining the use of BSC in small companies located within the UK and Cyprus (See Appendix 1). The majority were closed questions, with respondents having to choose the most suitable answer that is applied to their company. As a result, it was easier and faster for the respondents to answer each question. A few questions were open in nature since they required specific answers. Although open questions present greater problems at the analysis stage, they were structured and worded to avoid such problems (Bell, 2010). Identical questionnaires were sent to respondents in the UK and Cyprus, with the only difference being the national currency used within various questions.

The questionnaire itself was separated into four sections. The first section included six general information questions about the company, such as the average annual turnover, the number of employees, the principle activity etc. The majority of the questions were closed, except for one open question about the role of the respondent in the company since a more specific answer was needed to be provided. Furthermore there were two additional questions which were answered by choosing one option on a five point Likert scale. Afterwards, there was a brief explanation of the concept of BSC and the respondents were asked whether they are aware of the concept and if it used in their company.

The second section of the questionnaire was only answered by respondents whose company was actually using the BSC. Respondents were asked about how long their company has been using the BSC. Afterwards, there were sixteen questions about the effects of the BSC in their company. In order to measure the opinion of the respondents, a five point Likert rating scale was used (where $1=$ strongly agree, $2=$ agree, $3=$ neither, $4=$ disagree, 5 = strongly disagree).

The third section was answered by the respondents who were aware of the BSC but their company did not currently use it. They were asked a question about their reasons for not using the BSC and were then asked to continue on to the fourth section of the questionnaire.

The fourth section was answered by two types of respondent, those with no knowledge of the BSC and those with an awareness of the technique that did not currently use it. Respondents were asked two questions to identify the areas their company focused on and what key performance indicators they used to evaluate their companies' performance. Each respondent was provided with a list of key performance indicators together with a comment box to add any further measures that their company actually used.

In order to select a relevant sample of UK companies, the FAME (Financial Analysis Made Easy) website was utilised. FAME includes ten years of financial information for companies registered in the UK and Ireland, so it possible to identify a data set of UK companies which met two or more of the requirements necessary to be classified as a small size business. The Cypriot companies were identified through the Cyprus Chamber of Commerce and Industry (CCCI). The CCCI is a private corporate body which operates under special law with no state influence. It has useful information about the companies which are members of CCCI, i.e. company names, addresses, contact details and business activities (CCCI, 2008).

\subsection{Scope of the Survey}

According to Collis and Hussey (2009, p.209), 'a population is a body of people or collection of items under consideration for statistical purposes'. In this survey the population comprised small companies in the UK and Cyprus. In the UK, according to section 382 of the Company Act 2006, a company is considered as a small 
company if it meets two or more of the following requirements: a) a turnover no more than $£ 6.5$ million, b) a balance sheet total of assets no more than $£ 3.26$ million and c) no more than 50 employees.

'A sample is a subset of a population. In a positivist study, a random sample is chosen to provide unbiased subset that represents the population' (Collis and Hussey, 2009, p.209). In order to determine the sample size for this research, the estimated response rate was taken into account (Collis and Hussey, 2009). As a result, 250 questionnaires were sent to small companies in each country in order guarantee at least twenty responses from both the UK and Cyprus. 20 usable responses were obtained for each county.

Sekaran and Bougie (2010, p. 276), define convenience sampling as 'the collection of information from members of the population who are conveniently available to provide it'. This sampling method was used since it is the best method to collect necessary information fast and efficiently (Sekaran and Bougie, 2010).

\subsection{Limitations}

While a questionnaire provides a suitable and relatively inexpensive method for collecting data, this method of data collection does have its limitations. To begin with, many researchers contact companies in order to answer their questionnaires. Therefore, many people may be unwilling to reply to more surveys and as a result the number of responses will not be as high as expected (Collis and Hussey, 2009). Moreover, due to the low response rates the problem of biases appears (Collis and Hussey 2009; Oppenheim, 1992). The results of the survey may be biased due to the fact that the respondents of the questionnaire may not be representatives of the population (Collis and Hussey, 2009).

In order to avoid these problems, it is better to create the questionnaire as short as possible. Also, the questions would be better to be closed. Closed questions are also considered to provide higher questionnaire responses as they are generally easier and quicker to answer (Collis and Hussey, 2009).

\subsection{Conclusion}

This section discussed and explained the research paradigm used by this study. It also outlined the data collection process, the scope of the survey and the limitations of the work.

\section{Results}

\subsection{Objectives}

The main objective of this section is to analyse the results of the survey that was launched in small UK and Cypriot companies.

\subsection{Introduction}

This section starts with an analysis of the findings of the survey for the companies of each country, and continues with a review of the similarities and differences of the results of the two countries. A final subsection concludes this section.

\subsection{Analysis of the UK Small Companies' Findings}

A total of 500 questionnaires were emailed to small companies in the UK and Cyprus. A response rate of $8 \%$ was achieved (20 replies per country) which according to Collis and Hussey (2009) is expected.

In terms of the first two questions, regarding the average annual turnover and the number of employees of the company, all of the UK companies surveyed had a turnover up to $£ 6.5$ million and no more than fifty employees. This is in line with the criteria defining small sized UK companies discussed in sections 1 and 3.

In this survey there are participants from various economic and business sectors. The principal activity for $65 \%$ of the companies was the provision of services; $15 \%$ were wholesalers, with the remainder being construction and manufacturing companies.

The respondents were also asked about their role in their company to ensure that the people answering the questionnaires were involved in the company's strategy and aware of its mission and vision. According to the answers of the UK respondents, $50 \%$ had the role of the general manager, $15 \%$ were directors, and the rest were accountants, financial controllers or owners of the company. The position and calibre of the respondents indicates that credible information was provided, and as a result, valid and reliable findings can be made.

Within the survey, respondents were provided with a list of ten financial and non financial factors and asked to assess the relative importance of each within their company using a five-point Likert scale. The ten factors included on the questionnaire are generally accepted as having the potential to influence the performance of a company. As a result their "importance" cannot be easily dismissed or left unanswered even though a company 
might not actually perform them. The factors were not divided into financial and non financial indicators categories in order to receive unbiased and uninfluenced responses. Also the companies were given the option to assign the same level of importance to more than one factor. The financial factors provided were: the increase of sales, increase of profits, increase of revenue and increase of market share, while the non-financial factors included: the customer satisfaction, increase the number of customers, increase in productivity, improve the employees' skills, increase employees' satisfaction and improve the quality of products/services.

A graphical representation of the results is shown in Figure 4. 75\% of the surveyed UK companies stated that the increase of profits is a very important factor for their company. $60 \%$ of the companies are also stated that sales, revenues and customer satisfaction are very important. The improvement of product quality and the increase of productivity are considered very important factors to around $50 \%$ of the companies. The results clearly indicate a strong favourability within the UK companies to the financial factors.

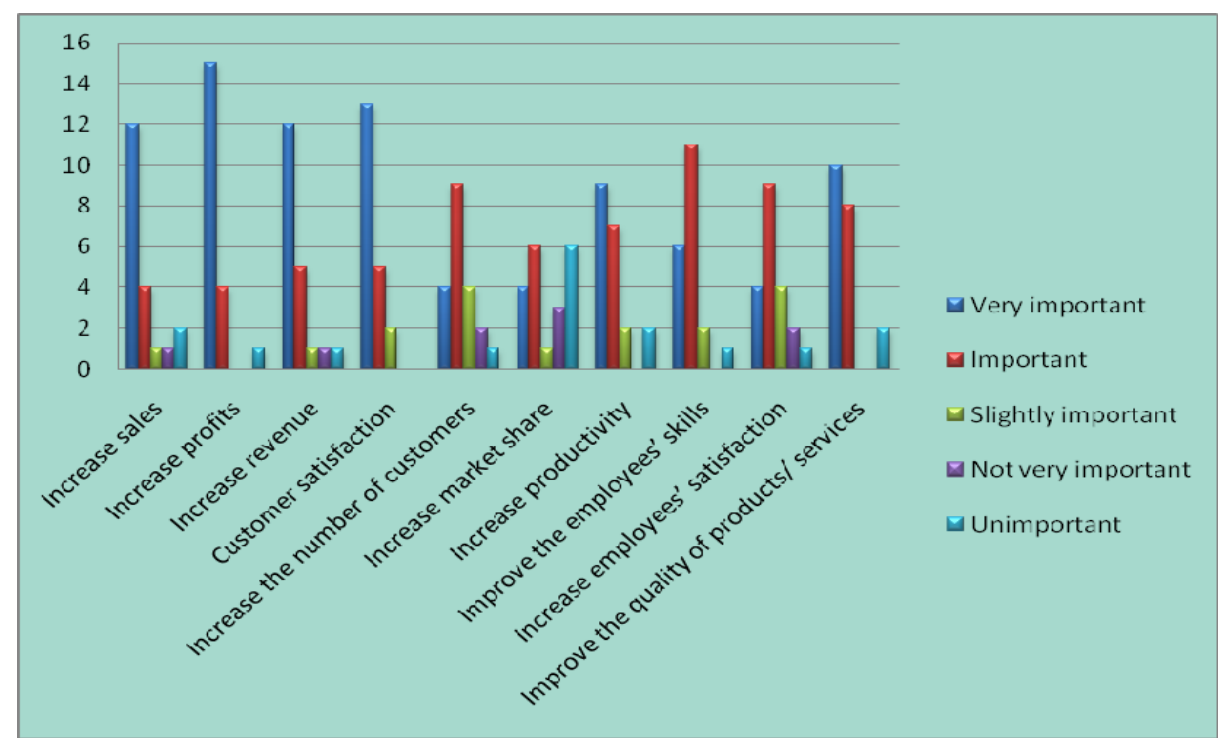

Figure 4. The importance of financial and non-financial factors for small UK companies

Most of the non-financial factors were used for their complimentary value. Specifically non-financial factors such as increasing the number of customers, improving employee skills, increase employee satisfaction and improving product quality received the level of "important" from $40 \%-55 \%$ of the companies replied.

As was discussed earlier, each of the ten factors included within the questionnaire are generally accepted as having the potential to influence the performance of any company. Nevertheless, companies with certain or unique characteristics (sector of activity, product mix, production process, competitors etc) are expected to acknowledge a limited importance or indifference to one or more of the factors under consideration. This acknowledgement was expressed via the low percentages of respondent replies on factors considered as "Slightly Important", "not very important" and "unimportant".

Increasing market share was not ranked especially highly by respondents. It received the highest percentages in the categories of "not very important" $(15 \%)$ and "unimportant" $(30 \%)$. These results are relatively unsurprising since all the companies surveyed were small sized and operating in large national markets. As a result, quantifying and targeting market share is hard to achieve and not seen as essential for such small entities.

The next question required that respondents indicate how important financial and non-financial performance measures were within their companies (question number 6, see appendix 1). The results correlate with the overall level of importance attached to the ten individual performance factors discussed earlier. $85 \%$ of respondents from UK companies stated that the use of financial measures were very important, with only $30 \%$ stating that non-financial measures were very important. This is according to the observation projected previously that there is a strong favourability within the UK companies to financial factors. Additionally, $55 \%$ of respondents stated that non financial measures are just important for the company, $10 \%$ believe that they are slightly important and $5 \%$ that are unimportant to the company. 


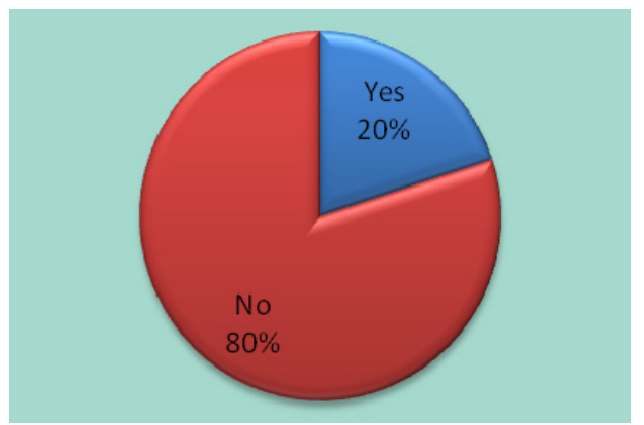

Figure 5. Awareness of the balanced scorecard by UK small companies

The questionnaire also investigated the popularity of the BSC and whether companies were aware of the technique. After a brief explanation of the concept of the BSC the respondents were asked if they are aware of the BSC tool. The results are shown in Figure 5, with $80 \%$ of respondents from UK companies unaware of what the BSC actually was. These results indicate a significant unawareness regarding this tool. The $20 \%$ of respondents who were aware of the BSC had first heard from a variety of channels, including academic literature, textbooks, seminars or lectures.

Only $25 \%$ of the UK companies with awareness of the BSC actually used the tool. This translates to one small company out of a total of four with awareness of the technique. The UK company that had implemented the BSC used it to develop strategy and believed the BSC to be an effective performance measurement system, relevant for use within smaller entities. The company was satisfied with the use of the BSC and considered it as a simple tool to enable employees to understand the strategy and vision of the company. Furthermore, the company agreed that the BSC provided information that could improve customer satisfaction, products/services delivery time, increase profits and to reduce costs. However, this company had a neutral opinion as to whether the BSC led to a better evaluation of company strategy and if it makes it easier to achieve the company's goals. Moreover, the respondent from the company did not agree or disagree as to whether the BSC provided useful information for improving the quality of the products/services, the employees' skills and satisfaction level as well as to increase the market share. The company's comment regarding the use of the BSC was that 'the primary use of the BSC is to keep the organization focused on the major stakeholders involved'.

In terms of the reasons why the other three small companies with awareness of the BSC did not use it, respondents indicated that they already use other performance measurement tools and they did not see the BSC as a relevant tool for use within smaller companies. These reasons correlate with the existing literature on the subject that was discussed earlier.

The last part of the questionnaire was devoted to companies that were either unaware of the BSC tool or did not use the technique. Respondents were asked whether they formally measured performance in certain key business areas (question number 15, see appendix 1). The business areas presented to respondents represented each of the four perspectives within the BSC. This was necessary in order to examine the possibility of companies applying performance measure indicators without being aware of their relativity to the BSC tool.

The findings show that the financial area is the most important, since $90 \%$ of companies formally measure performance against it. $53 \%$ and $58 \%$ of the companies formally measured the customer and internal business areas respectively. The innovation and learning area was only measured by $16 \%$ of the UK companies that were unaware of the BSC tool. These findings are in line with the results of the next question (number 16, see appendix 1) to which the respondents were asked to specify how regularly they use certain a performance measures. As shown in Figure 6, revenue growth, an indicator related with the financial area, was chosen by all companies as one of the key performance indicator most regularly used. However, number of new products was not used at all by more than half of all respondents. 


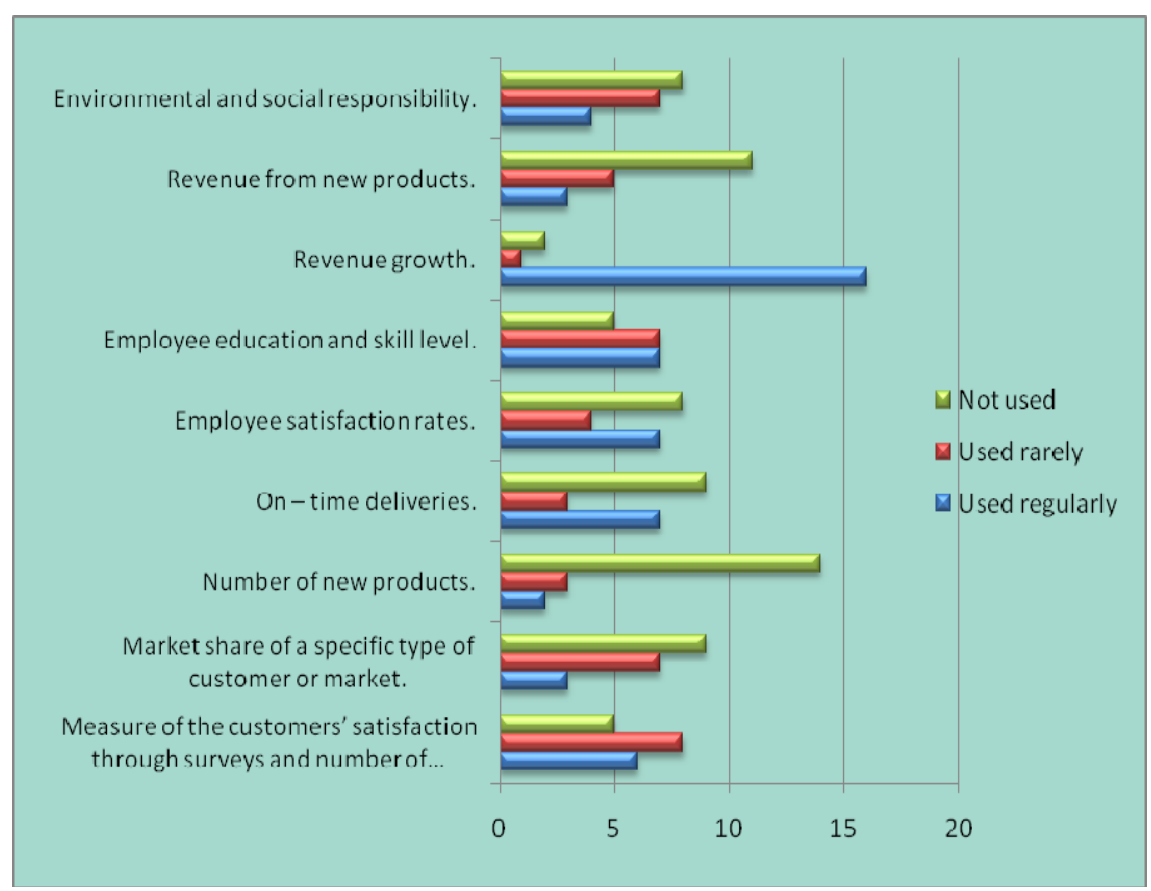

Figure 6. Key performance indicators used by UK small companies that either do not employ the BSC or are unaware of its existence

\subsection{Analysis of the Findings from Cypriot Small Companies}

All the Cypriot companies surveyed had ten or fewer employees. Consequently, the twenty Cypriot companies that participated can be defined as small companies since they meet the relevant discussed in section $1.30 \%$ of the Cypriot companies surveyed provided services, $25 \%$ were manufacturers and wholesalers and the rest being construction and insurance companies.

Cypriot respondents held different roles within their company but all related to the strategy and the vision of the company. $40 \%$ held the role of the general manager, $35 \%$ were directors and the rest were financial controllers, owners or had other roles. All of them were involved in the company's strategy.

Regarding the ten financial and non financial factors, most of the companies stated that all of the factors were very important, especially the increase of sales and the improvement of the products/services. The results are shown in Figure 7. The answers regarding the increase of the number of customers and employees' satisfaction were the only two factors which had more respondents that considered these factors as merely important. $80 \%$ of respondents at Cypriot companies stated that the use of financial measures is very important and $20 \%$ believed it to be important. In contrast, only $40 \%$ of respondents believed that non-financial measures are very important. $25 \%$ believed them to be important, $20 \%$ that they are slightly important, $10 \%$ that they are not very important and just $5 \%$ believe that they are unimportant. 


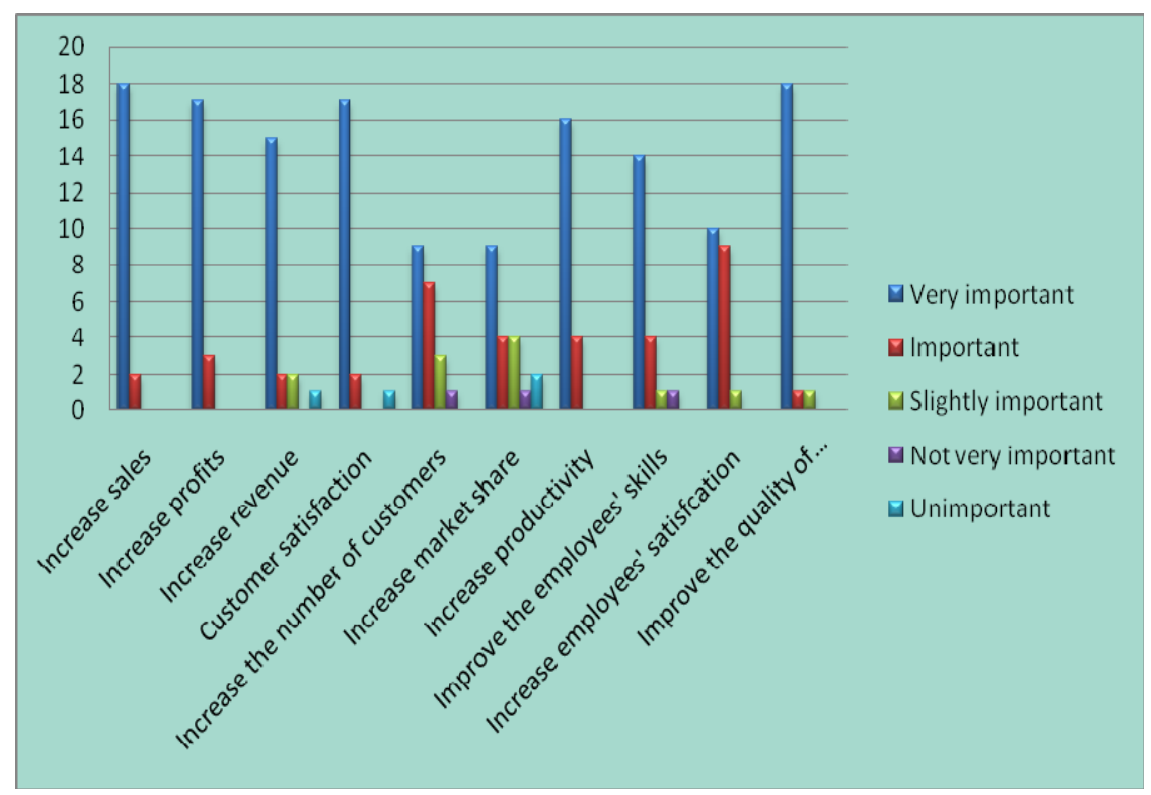

Figure 7. The importance of financial and non-financial factors for small Cypriot companies

As Figure 8 indicates, 55\% of respondents at Cypriot companies had never heard of this strategic performance management system. The $45 \%$ of respondents that were aware of the BSC had discovered it from academic literature or textbooks, seminars, consultants. One respondent has learned about the BSC from a professional journal.

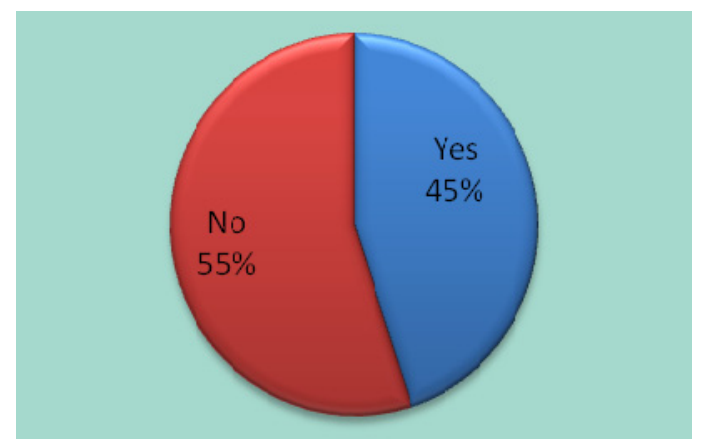

Figure 8. Awareness of the balanced scorecard in Cypriot small companies

At the nine Cypriot companies where respondents were aware of the BSC, only two or $22 \%$ actually used it. These two companies have been using the BSC for more than three years. According to their answers, both companies agreed that the BSC was an effective performance measurement system for their company and helped their employees better understand their company's strategy. Moreover, these respondents both agreed that the BSC provided information that helped managers improve customer satisfaction and the overall quality of products or services. For the rest of the questions their answers were different. While one company agreed that the BSC was a relevant tool for small businesses, the other company neither agreed nor disagreed. In addition, while one company strongly agreed that by using the BSC it was easier to achieve the company's goals and collect information in order to improve the employees' skills, the other one neither agreed nor disagreed.

At the majority of Cypriot companies that do not use the BSC, 57\% of respondents stated that they do not use it because they already used alternative performance measurements. $29 \%$ stated that they do not use the BSC because it is unsuitable for use within small companies. $14 \%$ believed that there is no reason to apply the BSC and the remaining $14 \%$ stated that the BSC is too time consuming to implement and use.

In order to better explore performance measurement at the Cypriot companies that either did not use the BSC or 
were unaware of the BSC, respondents were asked whether they formally measured performance across the four business areas within the BSC. $89 \%$ of these respondents formally measured customer satisfaction. Only $50 \%$ of companies measured performance for the internal business perspective and $61 \%$ measured their innovation and learning. Finally, the financial area is formally measured by $94 \%$ of these types of respondent companies.

Figure 9 illustrates they key performance indicators used by companies that either do not use the BSC or are aware of its existence. Revenue growth and on-time deliveries are the most widely used key performance indicators (KPI) by this classification of respondent company. In contrast, performance measures for environmental and social responsibility, revenue from new products and number of new products are either not used or rarely used.

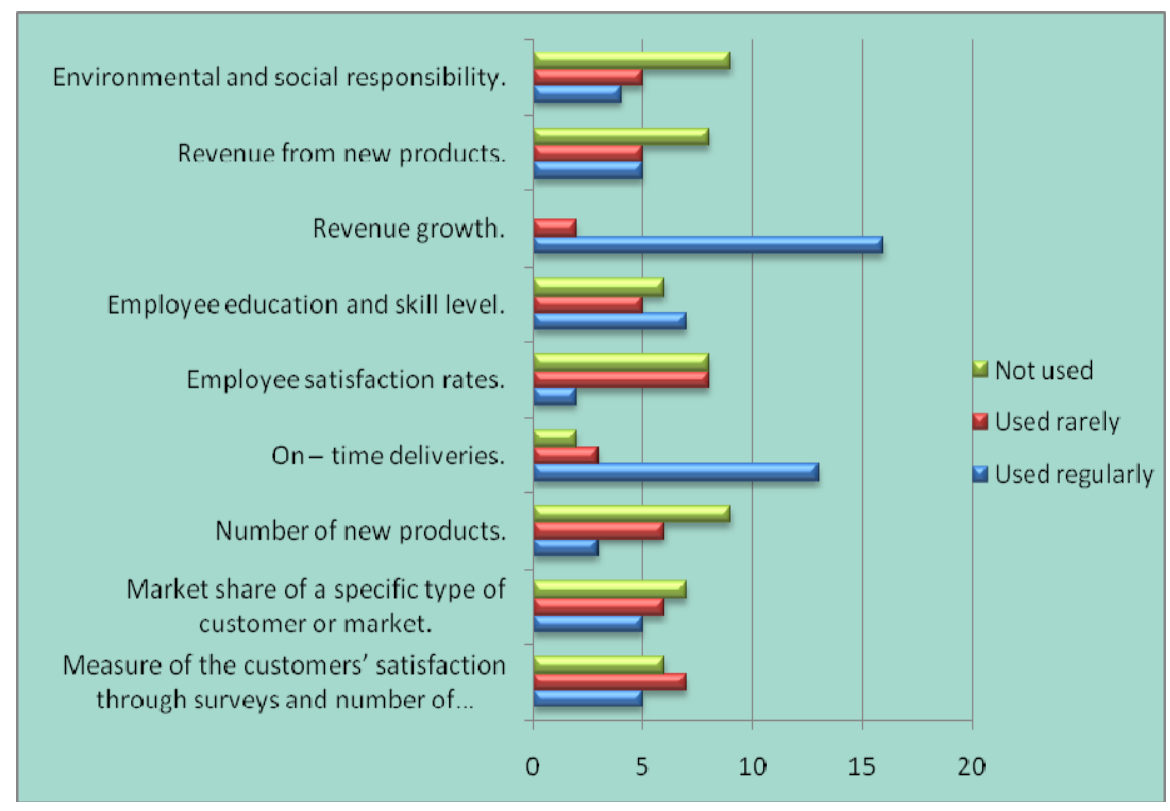

Figure 9. Key performance indicators used by Cypriot small companies that either do not employ the BSC or are unaware of its existence

\subsection{Comparative Levels of Balanced Scorecard Awareness and Use in Cyprus and the UK}

When comparing the survey evidence obtained from each country there appears to be a number of similarities but also significant differences between the two sets of results. A significant difference exists between the level of BSC awareness in each country. Awareness of the BSC in small companies is significantly higher in Cyprus (45\%) than in the UK (20\% awareness). Despite the increased awareness level amongst small companies in Cyprus, the percentage of "aware" companies actually using the BSC was virtually identical in both the UK (25\%) and Cyprus (22\%).

Respondents from companies in both countries agreed that the BSC can provide an effective performance measurement system for their company. However, there were different opinions about the relevance and effectiveness of this tool in the small companies. Of the three companies surveyed that used the BSC (one from the UK and two from Cyprus), two companies (one from the UK and one from Cyprus) agreed that the tool was suitable for use within small companies and could be used strategic management. The third company (from Cyprus) neither agreed nor disagreed with these statements.

There were similar responses between the two countries regarding the reasons for not implementing the BSC. The two most common reasons were that the company already had an effective performance measurement system in place or respondents believed that the BSC was unsuitable for use by small size companies.

As a result, a significant number of the UK and Cypriot small companies believe that the BSC is difficult to implement in small size companies. Also they believe that its use might not be as efficient and cost effective as in large companies.

In terms of the companies that either do not use the BSC or were unaware of its existence, the financial 
perspective of their operations was formally measured in some manner by almost all the companies in both countries. In addition, the majority of this type of Cypriot company formally measured the customer perspective, while only half of similar UK companies did so. A significance difference was apparent in the formal monitoring of learning and innovation. In Cyprus, $61 \%$ of the companies measured learning and innovation, while only $16 \%$ of small UK companies did so.

Revenue growth was regularly measured by the majority of UK and Cypriot companies. Although more than $50 \%$ of the Cypriot companies stated that they measured on-time delivery as a key performance indicator, almost $50 \%$ of the UK companies do not measure this at all.

\subsection{Limitations of the Research and Suggestions for Further Research}

The main limitation with this research is the relatively small size within each country's data set. Consequently, it would be advantageous if future research could be conducted using a larger sample of small companies. This could be done by examining small companies not only in the UK and Cyprus, but also in other countries.

Another limitation is that all of the research data was collected from questionnaires. Additional insights might be obtained about performance measurement and BSC awareness through face-to-face interviews with small company management.

\section{Conclusions}

While there is an extensive literature that explores the use of the BSC in large companies, there is a lack of empirical evidence regarding the use of the BSC in small companies. As a result, this study examined whether small companies in the UK and Cyprus were aware of the BSC and whether these companies have implemented and used the technique. In addition, this study attempted to identify the reasons why which small companies might not use the BSC for performance measurement.

Using data collected via a questionnaire sent to UK and Cypriot companies, the results indicate that small UK and Cypriot companies appear primarily focused on measuring the financial aspects of their performance. As a result, financial performance indicators are more prevalent in such companies and are given more importance than non-financial measures within decision making.

The majority of small UK and Cypriot companies do not formally use the BSC. One of the reasons for this is that many companies lack detailed knowledge and awareness about the BSC. Awareness of the BSC is higher in Cypriot small companies, although overall awareness levels in both countries was less than $50 \%$. In addition, for a significant number of small companies with awareness of the BSC, they chose not to adopt it due to a perception that tool is unsuitable for use by small companies. In total, only three of the forty UK and Cypriot companies surveyed actually used the BSC.

However, the survey results indicate that those companies that do not either use the BSC or are unaware of its existence, may actually use performance measurement approaches that are similar to those seen within the BSC. As a result, small companies may typically measure some or all of the four business areas prescribed by the BSC, using key performance indicators espoused by the authors of the BSC.

\section{References}

Andersen, H., Cobbold, I., \& Lawrie, G. (2001). Balanced Scorecard implementation in SMEs: reflection in literature and practice. Paper presented at the 4th SME international conference, Aalborg University, Denmark.

Anderson, E. W., \& Sullivan, M. W. (1994). The Antecedents and Consequences of Customer Satisfaction for Firms. Marketing Science, 12(2), 125-143. http://dx.doi.org/10.1287/mksc.12.2.125

Anthony, R. N., \& Govindarajan, V. (1998). Management Control Systems (9th ed.). Homewood: Irwin McGraw-Hill.

Bain \& Company guide. (2010). Balanced Scorecard. Retrieved July 5, 2012 from http://www.bain.com/publications/articles/management-tools-2011-balanced-scorecard.aspx

Bergen, C. W. V., \& Benco, D. C. (2004). A Balanced Scorecard for Small Business. Proceedings of the United States Association for Small Business and Entrepreneurship Conference. Dallas, Texas.

Bose, S., \& Thomas, K. (2007). Applying the balanced scorecard for better performance of intellectual capital. Journal of Intellectual Capital, 8(4), 653-665. http://dx.doi.org/10.1108/14691930710830819

Brennan, R. L. (2010). Statistics for Social Science and Public Policy: Generalizability Theory. New York: Springer. 
Bryman, A., \& Bell, E. (2007). Business Research Methods (2nd ed.). Oxford: Oxford University Press.

CIMA. (2009). Management Accounting Tools For Today and Tomorrow. Retrieved from http://www.cimaglobal.com/Documents/Thought_leadership_docs/CIMA\%20Tools\%20and\%20Techniques \%2030-11-09\%20PDF.pdf

Cobbold, I., \& Lawrie, G. (2002). The Development of the Balanced Scorecard as a Strategic Management Tool. 2GC Conference Paper. Retrievedv June 3, 2012 from http://www.2gc.co.uk/pdf/2GC-PMA02-1f.pdf

Collis, J., \& Hussey, R. (2003). Business Research: A Practical Guide for Undergraduate and Postgraduate Students (2nd ed.). Basingstoke: Palgrave Macmillan.

Collis, J., \& Hussey, R. (2009). Business Research: A Practical Guide for Undergraduate and Postgraduate Students (3rd ed.). Basingstoke: Palgrave Macmillan.

Collis, J., Holt, A., \& Hussey, R. (2012). Business Accounting: An Introduction to Financial and Management Accounting. Basingstoke: Palgrave Macmillan.

Companies Act. (2006). Section 382. Retrieved March 5, 2012 from http://www.legislation.gov.uk/ukpga/2006/46/section/382

Cyprus Chamber of Commerce and Industry. (2008). Retrieved June 27, 2012 from http://www.cci.org.cy

Donaldson, L. (2001). The Contingency Theory of Organisations. USA: Sage Publications.

Gumbus, A., \& Lussier, R. N. (2006). Entrepreneurs Use a Balanced Scorecard to Translate Strategy into Performance Measures. Journal of Small Business Management, 44(3), 407-425. http://dx.doi.org/10.1111/j.1540-627X.2006.00179.x

Hoque, Z., \& James, W. (2000). Linking balanced scorecard measures to size and market factors: Impact on Organizational Performance. Journal of Management Accounting Research, 12, 1-17. http://dx.doi.org/10.2308/jmar.2000.12.1.1

Hudson, M., Smart, A., \& Bourne, M. (2001). Theory and practice in SME performance measurement systems. International Journal of Operations \& Production Management, 21(8), 1096-1115. http://dx.doi.org/10.1108/EUM0000000005587

Jamil, C. M., \& Mohamed, R. (2011). Performance Measurement Systems (PMS) In Small Medium Enterprises (SMEs): A Practical Modified Framework. World Journal of Social Sciences, 1(3), 200-212.

Kaplan, R. S., \& Norton, D. P. (1992). The Balanced Scorecard - Measure That Drive Performance. Harvard Business Review, 70(1), 71-79.

Kaplan, R. S., \& Norton, D. P. (1996a). The Balanced Scorecard: Translating Strategy into Action. Boston: Harvard Business School Press.

Kaplan, R. S., \& Norton, D. P. (1996b). Using the Balanced Scorecard as a Strategic Management System. Harvard Business Review, 74(1), 75-85.

Kaplan, R. S., \& Norton, D. P. (1996c). Linking the Balanced Scorecard Strategy. California Management Review, 39(1), 53-79. http://dx.doi.org/10.2307/41165876

Kaplan, R. S., \& Norton, D. P. (2001). Transforming the Balanced Scorecard from Performance Measurement to Strategic Management: Part I. Accounting Horizons, 15(1), 87-104. http://dx.doi.org/10.2308/acch.2001.15.1.87

Kothari, C. R. (2004). Research Methodology: Methods \& Techniques (2nd ed.). Delhi: New Age International Ltd Publishers.

Kumar, R. (2005). Research Methodology: A Step-By-Step Guide For Beginners (2nd ed.). London: Sage Publications Ltd.

Mackay, A. (2004). A Practitioner's Guide to the Balance Scorecard. Leeds: CIMA.

McAdam, R. (2000). Quality models in an SME context A critical perspective using a grounded approach. The International Journal of Quality \& Reliability Management, 17(3), 305-323. http://dx.doi.org/10.1108/02656710010306166

Miller, E. (1959). Technology, Territory and Time: The International Differentiation of Complex Production Systems. Human Relations, 12(2), 243-272. http://dx.doi.org/10.1177/001872675901200304

Ministry of Commerce Industry and Tourism in Cyprus. (2012). Small Medium Sized Enterprises. Retrieved June 
30, 2012, from http://www.mcit.gov.cy/mcit/mcit.nsf/dmlsme_en/dmlsme_en?OpenDocument

Mintzberg, H. (1981). Organizational design, fashion or fit? Harvard Business Review, 59(1), 103-116.

Mitchell, F., Reid, G., \& Smith, J. (2000). Information System Development in the Small Firm. CIMA Publishing. Morgan, G. (1979). Response to Mintzberg. Administrative Science Quarterly, 24(1), 137-9.

Neely, A., \& Bourne, M. (2000). Why measurement initiatives fail. Measuring Business Excellence, 4(4), 3-7. http://dx.doi.org/10.1108/13683040010362283

Newing, R. (1994). Benefits of a balanced scorecard. Accountancy, 114(1215), 52-53.

Norreklit, H. (2000). The balance on the balanced scorecard - a critical analysis of some of its assumptions. Management Accounting Research, 11, 65-88. http://dx.doi.org/10.1006/mare.1999.0121

Oppenheim, A. N. (1992). Questionnaire Design and Interviewing and Attitude Measurement (New ed.). New York: Continuum.

Otley, D. (1980). The contingency theory of management accounting: achievement and progress. Accounting, Organizations and Society, 5(4), 413-428. http://dx.doi.org/10.1016/0361-3682(80)90040-9

Rigby, D., \& Bilodeau, B. (2011). Management tools and Trends 2011, Bain \& Company. Retrieved July 5, 2012, from http://www.bain.com/Images/BAIN_BRIEF_Management_Tools.pdf

Russo, J. (2005). The Balanced Scorecard in SMEs: The Case of the Plastic Industry in the Portuguese Central Region. Retrieved from http://joaorusso.com.sapo.pt/AOEFo5fulltext.pdf

Sainidis, E., Gill, R., \& White, A. (2001). Emergent strategies in SMEs. Paper presented at the 4th SME international conference, Aalborg University, Denmark.

Saunders, M., Lewis, P., \& Thornhill, A. (2009). Research Methods for Business Students (5th ed.). Essex: Pearson Education Limited.

Schoenfeld, H. M. (1991). Companies Managerial Accounting and Control in Multinational Companies: State of the Art and Unresolved Issues. In Sorensen P. E. (Ed.), New Perspectives in Management Accounting (pp. 57-106). Aarhus: The Aarhus School of Business.

Sekaran, U. (2010). Research Methods for Business: A Skill Building Approach (5th ed.). West Sussex: John Wiley \& Sons Ltd.

Sinha, A. (2006). Balanced Scorecard: A Strategic Management Tool. Vidyasagar University Journal of Commerce, 11, 71-81.

Zinger, J. T. (2002). The Balanced Scorecard and Small Business: A Stages of Development Perspective. Paper presented at the 47th International Council for Small Business Conference, San Juan, Puerto Rico.

\section{Appendix}

Appendix I

\section{$\underline{\text { The Questionnaire Format }}$}

Please check the boxes that are most applicable to you or feel in the blanks.

\section{$\underline{\text { Section } 1}$}

1. How much is the average annual turnover of your company? (Select only one)

$\square$ Up to $£ 6,500,000$

$\square £ 6,500,001-£ 10,000,000$

$\square £ 10,000,001-£ 50,000,000$

$\square$ More than $£ 50,000,000$

2. How many employees currently work for your company? (Select only one)

$\square$ Up to 50

$\square$ 51-100

口 101-200

口 More than 200 
3. What is the principal activity of your company? (Select only one)
$\square$ Manufacturing
$\square$ Service
$\square$ Wholesaler / Retailer
$\square$ Construction
$\square$ Transportation
$\square$ Other. Please Specify

4. What is your role in the company?

5. Please indicate how important each of the following factors is to your company.

\begin{tabular}{|c|c|c|c|c|c|c|}
\hline & $\begin{array}{l}\text { State the importance of the } \\
\text { following objectives for } \\
\text { your company. }\end{array}$ & $\begin{array}{c}1 \\
\text { Very } \\
\text { important }\end{array}$ & $\begin{array}{c}\mathbf{2} \\
\text { Fairly } \\
\text { important }\end{array}$ & $\begin{array}{c}3 \\
\text { Slightly } \\
\text { important }\end{array}$ & $\begin{array}{c}4 \\
\text { Not very } \\
\text { important }\end{array}$ & $\begin{array}{c}\mathbf{5} \\
\text { Unimportant }\end{array}$ \\
\hline 1 & Increase sales. & & & & & \\
\hline 2 & Increase profits. & & & & & \\
\hline 3 & Increase revenue. & & & & & \\
\hline 4 & Customer satisfaction. & & & & & \\
\hline 5 & $\begin{array}{l}\text { Increase the number of } \\
\text { customers. }\end{array}$ & & & & & \\
\hline 6 & Increase market share. & & & & & \\
\hline 7 & Increase productivity. & & & & & \\
\hline 8 & $\begin{array}{l}\text { Improve the employees' } \\
\text { skills. }\end{array}$ & & & & & \\
\hline 9 & $\begin{array}{l}\text { Increase employees' } \\
\text { satisfaction. }\end{array}$ & & & & & \\
\hline 10 & $\begin{array}{l}\text { Improve the quality of } \\
\text { products/ services. }\end{array}$ & & & & & \\
\hline
\end{tabular}

6. Please indicate how important each of the following types of performance measures are to your company.

\begin{tabular}{|l|c|c|c|c|c|}
\hline & $\begin{array}{c}\mathbf{1} \\
\text { Very } \\
\text { important }\end{array}$ & $\begin{array}{c}\mathbf{2} \\
\text { Fairly } \\
\text { important }\end{array}$ & $\begin{array}{c}\mathbf{3} \\
\text { Slightly } \\
\text { important }\end{array}$ & $\begin{array}{c}\mathbf{4} \\
\text { Not very } \\
\text { important }\end{array}$ & $\begin{array}{c}\mathbf{5} \\
\text { Unimportant }\end{array}$ \\
\hline Financial measures & & & & & \\
\hline Non financial measures & & & & & \\
\hline
\end{tabular}

7. The Balanced Scorecard (BSC) is a strategic performance management system which was developed by Kaplan and Norton in 1992. It is separated into four perspectives which are the following: customer perspective, internal business perspective, innovation and learning perspective and financial perspective.

Are you aware of the Balanced Scorecard? (Select only one)

$\square$ Yes

$\square$ No (Please go to question no. 15) 


\section{$\underline{\text { Section } 2}$}

8. Where did you first learn about the Balanced Scorecard? (Select only one)

$\square$ Professional journal

$\square$ Academic literature or textbook

$\square$ Financial press

\begin{tabular}{|c|c|c|c|c|c|c|}
\hline & $\begin{array}{l}\text { What are your views on the } \\
\text { following statements regarding the } \\
\text { Balanced Scorecard (BSC)? }\end{array}$ & $\begin{array}{c}1 \\
\text { Strongly } \\
\text { agree }\end{array}$ & $\begin{array}{c}2 \\
\text { Agree }\end{array}$ & $\begin{array}{c}\mathbf{3} \\
\text { Neither agree } \\
\text { or disagree }\end{array}$ & \begin{tabular}{c|}
$\mathbf{4}$ \\
Disagree
\end{tabular} & $\begin{array}{l}\mathbf{5} \\
\text { Strongly } \\
\text { disagree }\end{array}$ \\
\hline 1 & $\begin{array}{l}\text { The BSC is an effective } \\
\text { performance measurement system. }\end{array}$ & & & & & \\
\hline 2 & $\begin{array}{l}\text { My company is satisfied with the } \\
\text { use of the BSC. }\end{array}$ & & & & & \\
\hline 3 & $\begin{array}{l}\text { It is a performance measurement } \\
\text { tool relevant for small sized } \\
\text { companies. }\end{array}$ & & & & & \\
\hline 4 & $\begin{array}{l}\text { It is easy to apply the BSC in small } \\
\text { companies. }\end{array}$ & & & & & \\
\hline 5 & $\begin{array}{l}\text { With BSC is easier to achieve the } \\
\text { goals of the company. }\end{array}$ & & & & & \\
\hline 6 & $\begin{array}{l}\text { It evaluates better the strategy of } \\
\text { the company. }\end{array}$ & & & & & \\
\hline 7 & $\begin{array}{l}\text { It balances the long-term goals and } \\
\text { short-term goals of the business. }\end{array}$ & & & & & \\
\hline 8 & $\begin{array}{l}\text { With the BSC the employees } \\
\text { understand better the strategy and } \\
\text { the vision of the business. }\end{array}$ & & & & & \\
\hline 9 & $\begin{array}{l}\text { Information from BSC can help } \\
\text { managers to improve the customer } \\
\text { satisfaction. }\end{array}$ & & & & & \\
\hline 10 & $\begin{array}{l}\text { Information from BSC can help } \\
\text { managers to improve the quality of } \\
\text { the products/services. }\end{array}$ & & & & & \\
\hline 11 & $\begin{array}{l}\text { Information from BSC can help } \\
\text { managers to improve the } \\
\text { employees' skills. }\end{array}$ & & & & & \\
\hline 12 & $\begin{array}{l}\text { Information from BSC can help } \\
\text { managers to increase the } \\
\text { employees' satisfaction levels. }\end{array}$ & & & & & \\
\hline 13 & $\begin{array}{l}\text { Information from BSC can help } \\
\text { managers to increase market share. }\end{array}$ & & & & & \\
\hline 14 & $\begin{array}{l}\text { Information from BSC can help } \\
\text { managers to improve the } \\
\text { products/services delivery time to } \\
\text { customers. }\end{array}$ & & & & & \\
\hline 15 & $\begin{array}{l}\text { Information from BSC can help } \\
\text { managers to increase profits. }\end{array}$ & & & & & \\
\hline 16 & $\begin{array}{l}\text { Information from BSC can help } \\
\text { managers to reduce costs. }\end{array}$ & & & & & \\
\hline 17 & $\begin{array}{l}\text { Please state any other comments } \\
\text { you may have regarding to the use } \\
\text { of BSC in your company }\end{array}$ & & & & & \\
\hline
\end{tabular}


$\square$ Talk, seminar or lecture

$\square$ Consultant

$\square$ Internet site, forum or blog

$\square$ Other. Please Specify

9. Does your company use the Balanced Scorecard? (Select only one)

$\square$ Yes

$\square$ No (Please go to question no. 14)

$\square$ Unknown (Please go to question no. 15)

10. How long has your company used the Balanced Scorecard? (Select only one)

$\square$ Less than 1 year

$\square$ 1 -3 years

$\square$ More than 3 years

11. Please indicate your level of agreement with each of the following statements.

12. I would like to interview a selection of respondents in more depth in order to understand better the use of performance measurements and the BSC in the small size companies. Would you be willing to have a 10 minute interview with me about my research?

$\square$ Yes

$\square$ No

13. If yes, please provide below a telephone number and the time and day you would prefer to be called. Name (optional):

Contact telephone number:

Preferable time and day:

\section{$\underline{\text { Section } 3}$}

14. Why does your company not use the Balanced Scorecard? (Select as many reasons as apply)

$\square$ Already uses other performance measurement tool.

$\square$ It is not relevant for the size of my company.

$\square$ There is no need to apply the concept of Balanced Scorecard.

$\square$ Do not understand the concept of Balanced Scorecard.

$\square$ It is time consuming.

$\square$ It is expensive.

$\square$ Other. Please specify

\section{$\underline{\text { Section } 4}$}

15. Does your company formally measure performance in the following business areas?

\begin{tabular}{|l|l|l|}
\hline & \multicolumn{1}{|c|}{ Yes } & No \\
\hline Customers & & \\
\hline Internal business & & \\
\hline Innovation and learning & & \\
\hline Financial & & \\
\hline Other. Please specify & \multicolumn{2}{|l|}{} \\
\hline
\end{tabular}


16. Which of the following key performance indicators, (if any), does your company use to evaluate its performance?

\begin{tabular}{|l|l|l|l|}
\hline & $\begin{array}{c}\text { Used } \\
\text { regularly }\end{array}$ & Used rarely & Not used \\
\hline $\begin{array}{l}\text { Measure of the customers' satisfaction through } \\
\text { surveys and number of complains. }\end{array}$ & & & \\
\hline $\begin{array}{l}\text { Market share of a specific type of customer or } \\
\text { market. }\end{array}$ & & & \\
\hline Number of new products. & & & \\
\hline On - time deliveries. & & & \\
\hline Employee satisfaction rates. & & & \\
\hline Employee education and skill level. & & & \\
\hline Revenue growth. & & & \\
\hline Revenue from new products. & & & \\
\hline Environmental and social responsibility. & & & \\
\hline $\begin{array}{l}\text { Other. Please specify any other KPI's your } \\
\text { company may use. }\end{array}$ & & & \\
\hline
\end{tabular}

17. Please list which performance management tools (if any) your company uses.

18. Please state any further comments you may have about performance measurement in your company and the use of Balanced Scorecard with regard to the size of your company.

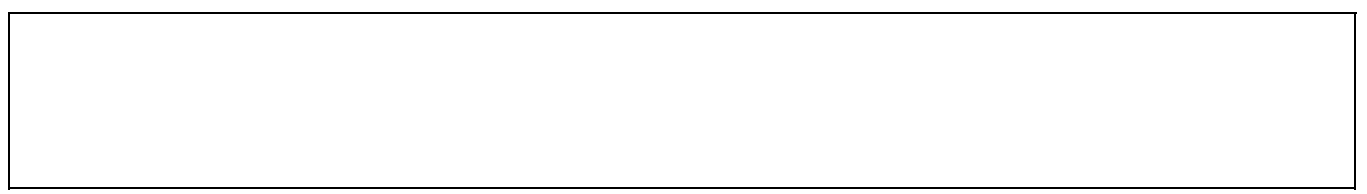

19. I would like to interview a selection of respondents in more depth in order to understand better the use of performance measurements and the BSC in the small size companies. Would you be willing to have a 10 minute interview with me about my research?
$\square$ Yes
$\square$ No

20. If yes, please provide below a telephone number and the time and day you would prefer to be called. Name (optional):

Contact telephone number:

Preferable time and day:

\section{Copyrights}

Copyright for this article is retained by the author(s), with first publication rights granted to the journal.

This is an open-access article distributed under the terms and conditions of the Creative Commons Attribution license (http://creativecommons.org/licenses/by/3.0/). 